\title{
Merchants Ambushed in Foreign Lands in the Late Middle Ages: The Case of Seafarers from Cuatro Villas in the North of Castile, Spain \\ Javier Añíbarro Rodríguez*
}

\begin{abstract}
After the War of the Castilian Succession (1475-1479), the Kingdom of Castile underwent major economic and commercial growth. The foreign policy of the Catholic Monarchs focused on strengthening political and trade links with other neighbouring powers such as England, Portugal and Flanders, and this was used by merchants to build up their wealth. However, the historian researching these merchants will discover that they suffered multiple attacks while undertaking their trade in supposedly friendly waters. This study will focus on assessing these attacks, learning what consequences they had for their victims and finding out how they could have been resolved. With this in mind, this paper shall take the example of seafarers from a region in Northern Castile known as Cuatro Villas de la Costa (Four Towns of the Coast) and discuss their experiences (sometimes as aggressors and sometimes as victims) to find out the mechanisms employed in Castile to solve conflicts generated at sea.
\end{abstract}

Keywords: Late Middle Ages, Seafarers, Castile, Piracy, Diplomacy, Trade

\footnotetext{
*PhD Assistant Professor. University of Cantabria, anibarroj@unican.es.
} 


\section{Introduction: Source and Methodological Aspects}

Prior to presenting this study, we should take into consideration some important aspects related to the nature of the sources that were examined. If we compare the amount and variety of late medieval documentation from Northern Spain (Atlantic coast) to that of Eastern Spain (Mediterranean coast), we will see that the former is much poorer and in shorter supply. There are no systematic journals or records of incidents on ships or attacks at sea; neither do we have access to records from custom offices at ports where the arrival or departure of ships and goods were registered. As a result, we lack stable data to know exactly what would happen in the vicinity of ports on a daily basis. These documents, which would be very useful for our purpose of investigating the past, were lost and this prevents us from providing any data of a quantitative nature. In other words, without sources of serial records, we cannot quantify the attacks, nor the financial losses in the medium or long term, nor define periods of greater or lesser conflict over time.

Fortunately, we do have other sources that help us reconstruct the past, namely sporadic news about attacks recorded in judicial proceedings and letters sent by the affected parties to the monarch for their lost wares to be replaced. In the case of the Kingdom of Castile, these documents are found mainly in two holdings at the General Archive of Simancas (Valladolid): the Seal of Court Registry and the Chamber of Castile. ${ }^{1}$

The Seal of Court Registry contains documents related to the administration of justice of first instance, and therefore we can find reports lodged by victims of the attacks. These documents tend to be brief, merely reporting what had happened and ordering the

\footnotetext{
${ }^{1}$ We shall henceforth use the following abbreviations. General Archive of Simancas GAS; Seal of Court Registry SCR; Chamber of Castile CC.
} 
courts to apply the rulings. They are useful for identifying the parties, determining the severity and type of offence and the court judgement.

In the Chamber of Castile archive, there are documents related to issues of special interest for the monarchy, such as the granting of mercy, privileges, etc. The information here tends to be much more extensive than the content of the Seal of Court Registry, and it is common to find testimonials from the affected parties asking for surety letters, protection, letters of marque and reprisal, restoration of rights, etc. ${ }^{2}$

Another methodological issue to consider is that only the cases mentioned in the conserved judicial sources are known, but there will certainly have been other unreported attacks, either because those affected could not report them to the courts (for whatever reason, from the lack of economic resources to the death of the victims in the violent episode) or simply because the records of the incident were lost or destroyed.

Furthermore, the historian should be aware of the biased nature of the sources and therefore exercise caution. When the researcher works with court cases or reports resulting from attacks and robberies, they tend to think that violent episodes were commonplace in late medieval trade and may attach excessive importance to them. They should, at this point, remember that they are working with specific sources that only speak of conflicts or failed trading opportunities and not of successful businesses brought to fruition.

\footnotetext{
2 Ángel de la Plaza, Archivo General de Simancas. Guía del investigador (Valladolid, Dirección Nacional de Archivos Históricos, 1992) 145-152; 167-172.
} 
In this sense, certain questions will occur to the historian: How frequent were episodes of maritime violence? Does the fact that judicial sources contain many cases of reports about violent attacks allow us to speak of widespread violence on the seas? Was it common for a particular merchant to be attacked at sea? Is it possible to answer these questions using sources with so many limitations and shortcomings such as those from the ports of Cuatro Villas? This paper will now proceed to answer these questions after presenting the cases studied.

\section{Cuatro Villas de la Costa: Geographical Location and Economy}

Cuatro Villas de la Costa was the name of the territorial jurisdiction of the Kingdom of Castile known as a 'county', which consisted of four ports belonging to the Castilian king: San Vicente de la Barquera, Santander, Laredo and Castro Urdiales. ${ }^{3}$ They are located in the central part of the Cantabrian Sea, on the Southern fringe of the Bay of Biscay. The councils of these four towns monopolised control of maritime traffic between the coasts of the present-day Basque Country and Asturias, while also participating in Atlantic trade by shipping goods to destinations such as Ireland, England, Flanders, France and Portugal. ${ }^{4}$

The economy of the area around Cuatro Villas was poor. The climate conditions and geological characteristics of the soil rendered it impossible to properly grow grains such as wheat, and therefore it was necessary to import them by land or sea. ${ }^{5}$ Road communications between Cuatro Villas and inland Castile were relatively deficient in

\footnotetext{
3 Juan Baró Pazos, 'Laredo y el Corregimiento de las Cuatro Villas de la Costa' in Margarita Serna Vallejo (ed) El fuero de Laredo en el octavo centenario de su concesión (University of Cantabria, 2001) 367-404.

4 Javier Añíbarro Rodríguez, Las cuatro villas de la costa de la mar en la Edad Media: Conflictos jurisdiccionales y comerciales (DPhil thesis, University of Cantabria, 2013) 383.

${ }^{5}$ Beatriz Arízaga Bolumburu, 'La actividad comercial de los Puertos Vascos y cántabros medievales en el Atlántico’ (2008) 35 Historia. Instituciones. Documentos 25.
} 
the Late Middle Ages; merchants travelling in the late fifteenth and early sixteenth century would complain about the poor state of the roads and tracks, while also warning of the deterioration of bridges. On top of that, the journey was complicated: standing about $50 \mathrm{~km}$ south of the coast was a large mountain range with peaks of over $2500 \mathrm{~m}$, which during the Middle Ages and the Early Modern Period conditioned the transport of goods, making it impractical in the event of winter snowfall. Part of the grains that fed the settlements located north of the Cantabrian mountain range would arrive from the Castilian Plateau along tortuous tracks that required constant maintenance. This land route was also important to the economy of the Kingdom of Castile because it was used to transport Castilian wool from cities such as Burgos to the ports of Santander and Laredo, from where it was shipped to other European destinations, especially Flanders. ${ }^{6}$

The poor land communications of Cuatro Villas were offset by its access to the sea. In fact, maritime activities such as freight and fishing were the true economic driving forces that triggered the development of these urban centres. The inhabitants of Cuatro Villas specialised in the export of products such as wool and iron, as well as in catching and importing fish that would later be sold around inland Castile. ${ }^{7}$ These pursuits forced merchants to navigate the waters of Atlantic Europe, which is why they were exposed to attacks at sea.

Likewise, some of these merchants sailing around Atlantic Europe saw piracy as an opportunity to become rich. Consequently, seafarers from Cuatro Villas are an excellent

\footnotetext{
${ }^{6}$ Jean-Pierre Molénat, 'Chemins et ponts du Nord de la Castille au temps des Rois Catholiques' (1971) 7 Melanges de la Casa de Velázquez 115; Lorena Fernández González, Santander una ciudad medieval (Stvdio, 2001) 121-153.

${ }^{7}$ See Arízaga (n 5) 26.
} 
example for learning more about violence at sea, as they were both victims and perpetrators.

\section{Maritime Violence Suffered by Merchants from Cuatro Villas}

\section{Areas of Conflict: Where would Attacks take Place?}

Violent maritime attacks would take place at any location where the attackers felt that they held a position of advantage. The danger of assailants boarding ships seems to have been greater in the vicinity of ports, especially when the merchant was travelling in foreign waters. $^{8}$ These areas were exposed to enemy attacks because they were obligatory routes for ships and local authorities were not able to exercise a close watch over them. Also, if the assailants were residents of nearby towns, they had the advantage of knowing the terrain and using it to their favour.

The first case we are going to consider takes place halfway between the open sea and the port. García de Escalante, a resident of Laredo who owned a business with two other residents of Bilbao, filed a complaint in 1484 that three of his ships had been attacked as they were sailing to Flanders laden with wool, iron, wine and fruit. ${ }^{9}$

The fact that the three caravels were travelling together was due to safety; sailing in a convoy provided better defence against a possible enemy attack, even though it would prolong the journey. Even so, travelling in a group did not guarantee immunity to

\footnotetext{
${ }^{8}$ Betsabé Caunedo del Potro, Mercaderes castellanos en el Golfo de Vizcaya (1475-1492) (Universidad Autónoma de Madrid, 1983) 205.

9 Luis Suárez Fernández, Política Internacional de Isabel la Católica: estudios y documentos (Universidad de Valladolid, 1969) Vol 2, 335. AGS RGS (1485) MS RGS,LEG,148511,97.
} 
enemy attacks if they were launched in an effective and organised manner, as happened in this case. ${ }^{10}$

The victims described the place and time of the assault, reporting that they were waiting on sandbars close to Flanders for the tide to rise and subsequently enter the port. That was when some ships attacked them. Escalante's men identified their assailants: the captains were Pinel and Potas (how the scribe noted down their names in Spanish), with the crew being formed by people from the County of Flanders. They also vouched that the attackers had set sail from Middelburg, a major nearby port that they used as an operating base and where they had stocked up on weapons used in the attack.

In other words, the assault was carried out by local people at a specific time when the Castilians were in a helpless situation because they could not enter the river mouth due to an excessively low tide. In addition, the sandbars and mud banks were real traps for seafarers who did not know the underwater topography of the area, and the attackers probably knew from which position it was more advantageous to launch the attack.

The Castilians said they went into battle against their will and lost, meaning that the assailants took them as prisoners. The captors later took them to Denmark, where they threw all the Castilians overboard so that no living witnesses of the act of villainy would remain. However, three of them managed to escape by swimming to dry land.

From that moment on, the victims attempted to secure compensation because the attack had occurred when there was peace and alliance between the County of Flanders and

${ }^{10}$ See Caunedo del Potro (n 8) 207. 
Castile. First of all, the three men who survived the attack went to the authorities of Middelburg. However, they were ignored by the authorities of that town, with even the scribes refusing to register their testimony in writing. This is probably where and when the Castilians actually identified their attackers by questioning people in places such as the docks and the port and not during the assault at sea.

We should realise that acquiring this kind of information and reporting it to the courts was not an easy task: first of all, the victims were foreign, which already made them suspicious in the eyes of locals; secondly, they probably did not speak the local language, which would have greatly hindered communication with the authorities and inhabitants of Middelburg; and thirdly, they were without any financial resources, because they had been assaulted. Therefore, one might ask, how did the Castilians manage not only to survive the attack without money, but also to report the incident to the authorities?

The sources do not explain these details, but it is not difficult to imagine that the Castilians had some sort of help. In this sense, years ago Avner Greif, Paul Milgrom and Barry R Weingast analysed how guilds of English merchants functioned overseas, concluding that the organisation and collaboration between rivals could actually be much more beneficial in the long term than individual competencies. ${ }^{11}$

In the same vein, Hilario Casado pointed out that among European merchants there was a network of solidarity based on trust and mutual assistance, in which the natives of one

\footnotetext{
${ }^{11}$ Avner Greif, Paul Milgrom and Barry R Weingast, 'Coordination, Commitment, and Enforcement: The Case of the Merchant Guild’ (1994) 102 Journal of Political Economy 773.
} 
kingdom would play a role. ${ }^{12}$ These networks meant that if a merchant was experiencing a dangerous event in a foreign land, all they had to do was contact a fellow merchant and the whole network would be set into motion: assistance, support, lending of money and, of course, information.

In the specific case of García de Escalante's men, they probably contacted other Castilian merchants and then sent a report of the incident to their captain. From Castile, García de Escalante and his cohorts would have been able to send them the necessary resources and instructions to follow in order to commence judicial proceedings.

Another possibility is that the company had a trusted agent or man waiting for the goods in the destination city. ${ }^{13}$ In that case, the agent, who would have accurate information and be aware of rumours in the area, would have launched an investigation in order to find out what had happened to the ship, the load and the crew. At the same time, the agent would send his reports to Castile and inform his superiors about the incident.

All this leads us to believe that the identification of the attackers would not have necessarily occurred during the assault, but that there were other mechanisms to identify the perpetrators of the robbery. In the specific case in question, there is evidence pointing to the fact that information was obtained, or at least was verified, after the attack: the attacking crew is said to have been formed by 'people from the County of

\footnotetext{
${ }^{12}$ Hilario Casado Alonso, 'Las redes comerciales castellanas en Europa (siglos XV y XVI)' in Hilario Casado Alonso and Antonio García-Baquero (eds), Comercio y hombres de negocios en Castilla y Europa en tiempos de Isabel la Católica (Sociedad Estatal de Conmemoraciones Culturales, 2007) 279307.

${ }^{13}$ Betsabé Caunedo del Potro and Margarita Sánchez Martín, 'Cláusulas comerciales: ¿AAcatamiento o transgresión? El factor de negocios en la Europa Atlántica’ in Jesús A Solórzano Telechea, Beatriz Arízaga Bolumburu, Louis Sicking (eds), Diplomacia y comercio en la Europa Atlántica Medieval (Instituto de Estudios Riojanos, 2015) 187-219, 194.
} 
Flanders', something which could easily have been noticed if the victims had recognised the language that the attackers were speaking during the skirmish. They also identified the names of the ringleaders of the assault, a more difficult task, but somebody might have been able to understand the language and pay attention to the person giving the orders. But in our opinion, knowing that they had armed themselves and set out from Middelburg must have in all probability involved an investigation.

However, we should remember that the captains Pinel and Potas had decided to dispose of the witnesses by throwing them into the sea. Therefore, one might wonder: were the attackers aware that they had been identified during the boarding and therefore wanted to rid themselves of the witnesses? In this regard, it should be noted that the documentation we consulted does not often include orders to kill the victims; it was commonplace for the attackers to intimidate the crew, who would then surrender without offering much resistance. ${ }^{14}$ García de Escalante, however, indicated that his men had faced up to and fought with their attackers, which - in our opinion - could have been the cause that influenced the drastic decision of Pinel and Potas.

In any case, the findings of García de Escalante and his cohorts in the Netherlands were of little use, as once they reported what had happened in Middelburg, the authorities ignored them. They had to pursue their claims in Castile, namely before the Royal Court of Justice, which granted them a licence to effect a reprisal of the goods from the residents of Middelburg.

\footnotetext{
${ }^{14}$ But there were exceptions. Iñaki Bazán, “"Degollaron a todos los dichos treynta e tres yngleses e asy degollados dis que los laçaron en la mar”. Las hermandades vascas y la lucha contra la piratería en la Baja Edad Media’ (2006) 5 Itsas Memoria. Revista de Estudios Marítimos del País Vasco 83, who recounts how two Basque killed an English crew slept at night while taking advantage of their helplessness.
} 


\section{Letters of Marque and Reprisal: A Problematic Solution}

The fact that the monarch granted a letter of marque and reprisal to one of his subjects entailed a statement of diplomatic failure. The monarch was very reluctant to grant such licences, usually requiring the prosecuting party to have exhausted all possible legal avenues in the kingdom of the aggressors. If the justice system in the kingdom of the aggressors ignored the attacked parties, and the latter managed to prove that the thieves belonged to that particular realm, then the prosecuting party could start a legal process in its home kingdom to serve a letter of marque. ${ }^{15}$

However, granting letters of marque was not an effective solution. ${ }^{16}$ First of all, they did not solve the problem of the theft, but just transferred it to third parties. Second, it was left in the hands of the aggrieved parties to recover the lost goods, which would often lead to more violence and abuse. And thirdly, they had a negative effect on trade and diplomatic relations between the kingdoms in question. Neither were they the ideal solution for the claimant: the aggrieved merchant had to receive payment by force and this meant risking his men and his ships. Moreover, immediate compensation was not secured and, to top it all off, letters of marque would expire when the two kingdoms reached diplomatic agreements, so many ended up without retribution being exacted. ${ }^{17}$

We know of a resident of Laredo who suffered retaliation because of other subjects of the kingdom, namely some Basques from Guipúzcoa. The merchant was called Sancho González de la Obra, and in 1488 was trading in Ireland between the towns of Youghal

\footnotetext{
${ }^{15}$ Michel Bochaca, Beatriz Arízaga and Mathias Tranchant, 'La violence en mer et dans les ports du golfe de Gascogne à la fin du Moyen Âye: bilan et perspectives de recherche' in Mikaël Augeron and Mathias Tranchant (dirs), La Violence et la Mer dans l'espace atlantique (XIIe XIXe siècle) (Presses Universitaires de Rennes, 2004) 27-50.

${ }^{16}$ See Caunedo del Potro (n 8) 234.

${ }^{17}$ See Bazan (n 14) 77.
} 
and Kinsale. ${ }^{18}$ On the journey between the two ports, around sixty armed men set out in several boats from the town of Cork and boarded the vessel. The merchant was taken prisoner and held captive in a tower in Cork for six months with shackles on his hands and feet. To secure his release, he had to pay three hundred gold crowns, which his captors had already taken when he was detained, plus the load on the ship.

The interesting thing about this case is that the residents of Cork admitted that they had nothing against Sancho González, but that they had imprisoned him in retaliation for some Basques from Guipúzcoa having stolen up to four thousand crowns when there was peace between England and Castile. This time, the Irish had been able to identify not only the origin of their aggressors, but also their names: Jofre de Sasylo, San Juan de la Peña, Juan Ochoa de Licona and Pascual de Aguirre, among others. This information was conveyed to Sancho González for him to claim the goods back through the Spanish justice system. Indeed, upon reaching his home kingdom, he was able to identify the attackers of the Irish: they were powerful, well-known people in the province of Guipúzcoa, but the Catholic Monarchs summoned them to return to Sancho González what the Irish had taken from him due to their actions. ${ }^{19}$

Few letters of marque may have been granted, but a stand-out example is the one sent in 1479 by Ferdinand the Catholic to Juan de Urueña, Diego de Villaviciosa and Juan Ferrero, merchants from San Vicente de la Barquera. ${ }^{20}$ This is a very interesting document because it reveals the many problems caused by granting letters of marque. These Castilian sailors were carrying wine, oil, figs, raisins and other goods to

\footnotetext{
${ }^{18}$ See Suárez (n 9) Vol II, 109.

${ }^{19}$ See Caunedo (n 8) 236.

20 ibid, 237.
} 
Ilfracombe (near Bristol, England), but on reaching port were assaulted by locals, who boarded the ship armed with bows, swords and other weapons. ${ }^{21}$ The attackers said that they were taking hold of their ships and goods because they were Portuguese. The Castilians explained that they were not subjects of the king of Portugal, but natives of the Kingdom of Castile, yet their objections were of no use.

With few resources, the merchants headed to London, where they submitted their case to the authorities. This time the Castilian merchants found refuge in justice, which granted them a letter for the residents of Ilfracombe to return the seized goods. However, when the Castilians were one league away from Ilfracombe, approximately one hundred armed men set out with the purpose to intimidate them. The residents of Ilfracombe only agreed to return the boat and half of the goods, with the Castilians being forced to accept this. Upon boarding, the merchants from San Vicente found that half of the load was damaged. Faced with circumstances that discouraged the Castilians from presenting a complaint or renegotiating with the locals, they chose to leave the town as soon as possible and accept that the load had been lost.

But Juan de Urueña and his men did not give up and decided to return to London. Once there, the king gave them a document to submit to the mayor of Bristol. This document ordered all goods belonging to residents of Ilfracombe in Bristol to be commandeered and, therefore, compensate the Castilians. When the mayor of Bristol received the letter, he did not immediately comply; in fact, he delayed its implementation for more than fifteen days, at which time the Castilians chose to go directly to justice and bring criminal prosecutions against the mayor of Bristol and the residents of Ilfracombe.

${ }^{21}$ See Suárez (n 9) Vol I, 451. 
Ruined and penniless in England, the Castilians decided to return to Castile, where they presented their case to the monarch. Under the circumstances, Ferdinand the Catholic granted them a letter of marque against the residents of Ilfracombe in 1479.

There is another better-known case that illustrates the difficulties of a merchant receiving retribution following a letter of marque. This is the case of Fernando del Hoyo, a resident of Laredo, against Cornelis Deque, a Flemish merchant living in Valladolid. ${ }^{22}$ This episode has already been studied by Raymond Fagel, so we shall not dwell on it too much. The case can be summarised as follows: Fernando del Hoyo was attacked by Flemish merchants near Flanders in 1489, within the context of the rebellions taking place in this region in the late fifteenth century. As a result, in 1492 he obtained a letter of marque from the Catholic Monarchs, which he executed on the goods of Cornelis Deque, a merchant of Flemish origin but who had settled in and become a resident of the city of Valladolid.

It was a very complicated legal process for the courts and was particularly uncomfortable for the monarch, as both Cornelis Deque and Fernando del Hoyo had a certain influence on the government. Fagel decried the fact that the final ruling of the process was unknown, as no documented proof remains, but he sensed that Cornelis Deque regained his goods and that Fernando del Hoyo reached an agreement with Philip

\footnotetext{
${ }^{22}$ Raymond Fagel, 'Cornelis Deque, un mercader flamenco en la Castilla del siglo XV. Un debate sobre el concepto de "vecindad” y "naturaleza” entre mercaderes', in Hilario Casado Alonso (ed), Castilla y Europa. Comercio y mercaderes en los siglos XIV,XV y XVI (Diputación Provincial de Burgos, 1995) 241-263.
} 
I of Castile. A Royal Decree issued in 1494 to a close relative of the Castilian merchant pointed in that direction. ${ }^{23}$

Fagel was indeed on the right track: an agreement was reached with the monarch to solve the discombobulation of Fernando del Hoyo's letter of marque, but the document proving this is from a later date, namely 1512. This is a case between Fernando del Hoyo Villota, a resident of Laredo, against the city of Burgos about the possession of a load in the regiment of Burgos. ${ }^{24}$

We doubt that this Fernando del Hoyo Villota is the same one who received the letter of marque, but if not he was a very close relative. As stated in the document, the Crown had granted him a solution for the first regiment to be convened in Burgos in exchange for and equivalent to a reprisal of 17600 ducats, an amount which corresponds to the letter of marque that Fernando del Hoyo executed on Cornelis Deque.

Twenty-three years had passed since the merchant of Laredo had been attacked; in the meantime, several court cases, agreements and negotiations occurred. We should also remember that not even the agreement ruled by the Crown more than two decades later was final, as the city of Burgos had contested that decision.

\section{The Power of the Aggressors in their Homeland}

The next event that will be analysed also took place in the vicinity of another port of the British Isles. To be precise, it occurred in Bantry Bay, in the southwest of Ireland, in

\footnotetext{
23 ibid, 256.

${ }^{24}$ AGS Consejo Real de Castilla (1512/1513) MS CRC,2,8.
} 
September $1514 .^{25}$ The document that recorded this episode is highly valuable for the historian because it contains the written testimony of the interrogation of the witnesses who experienced the events.

This time the victim was Pedro Gutiérrez de Comillas, a resident of San Vicente de la Barquera, and his crew, which consisted of four other men and two boys. They were visiting the Irish coast in search of cheap fish to sell in Castile, where its price had doubled. For this purpose, Pedro Gutiérrez loaded up with white and red wine, alum, silk, coral, saffron, salt and other luxury goods which he sold at some ports to obtain Irish currency with which he could do business on the island.

As they were heading to the town of Bantry, the ship was boarded by a dozen men armed with bows and arrows, swords and long knives. Unlike the case discussed earlier, this time the victims did not put up any resistance or fight back. The assailants disarmed Pedro Gutiérrez and his men, then tied their hands behind their backs to immobilise them. Some witnesses even claimed that Pedro Gutiérrez had a head collar strapped around his head. After stealing everything they had with them, including victuals and clothes, they were led to a hill and abandoned to their fate.

If one reads the document relating the events carefully, it is possible to determine that the assault did not take Pedro Gutiérrez by surprise because he gave one of the boys a bag of money to escape and find help. In fact, the boy managed to enter the church of a Franciscan monastery near Bantry and take refuge there. However, the assailants found

\footnotetext{
${ }^{25}$ See Añíbarro (n 4) 598. AGS CC (1515) MS AGS CC Pueblos leg 17 doc 360.
} 
him and had no qualms about storming into the church to steal the money from him and take him prisoner along with his compatriots.

At this point, the reader may have certain questions: How did the attackers know that the young man was in the church? Why did the citizens and authorities of Bantry not go to see what was happening when a group of armed men forcibly dragged a young man out from a church? And why did the Franciscan monks let their sacred space be violated? These questions are revealed when the identity of the ringleader of the attackers is explored.

The Castilians called him Danol de Sulvian, which was the phonetic form of pronouncing his actual Irish name, Donal O'Sullivan. His name and face were famous throughout the county because he was the firstborn of Donal O'Sullivan, Lord of the Beara Peninsula and the town of Bantry.

Once this fact is revealed, the pieces of the puzzle start to fit together; the Castilians did not offer any resistance because they knew their attackers personally, and realised that they could not face up to them. In fact, the interrogation conducted on the merchants when they returned to Castile stated that all Castilians who regularly visited Ireland knew both Donal (father) and his son.

For the same reason, it would not have been difficult for the son of the local lord to find out that a foreigner had just taken refuge in a nearby church, and of course, neither were the civic guard of Bantry or the monks going to oppose his forced removal. It also does not come as a surprise that the local authorities, starting with Donal O'Sullivan (senior) 
himself, would ignore the Castilians when they made a claim for the items taken by his son.

However, one question remains unclear: why did Donal O'Sullivan (junior) decide to rob the Castilians? The Castilians swore that they often visited that area and paid the fees and insurance related to trading and fishing; in other words, they were indirectly making a positive contribution to the local economy. The estimated price of the stolen items (all the merchandise, ships, provisions, clothes and money obtained by trading for three months) was approximately 50000 maravedies, a significant amount in the Castilian currency. However, actions such as those perpetrated by Donal O'Sullivan (junior) had a negative impact on his father's interests: if the Castilians were to avoid sailing off the Beara Peninsula, they would also stop replenishing provisions, trading and paying taxes in that area.

Another possibility is that the Castilians had not paid the relevant rights of way; or if they had, there may have been a political problem beyond their control. It is true that from the second half of the fifteenth century, coinciding with the increased traffic of English and Castilian vessels in Irish waters, the English crown saw it fit to tighten fiscal surveillance in the area. That decision was not to the liking of local chiefs, as it limited their autonomy and also created political tensions. ${ }^{26}$ Therefore, one could consider the hypothesis that the Castilians had previously paid insurance to the English authorities and the former's insistence that they had already paid the fees triggered the events described above.

\footnotetext{
${ }^{26}$ Maryanne Kowaleski, 'The expansion of the south-western fisheries in late medieval England' (2000) 53(3) The Economic History Review, New Series 443.
} 
But in that case it would have been logical for Donal O'Sullivan (junior) and his men to confiscate the load and, at most, arrest the crew and take them to the town. The fact that the Irish stripped the Castilians naked and left them to their fate on a hill suggests that they were acting without the authority of Donal O'Sullivan (senior). In addition, and unlike the case in Flanders, nobody died in the incident because it was unnecessary; Donal O'Sullivan (junior) was aware of his position and that his actions would not be punished, regardless of whether any witnesses survived or not. This would explain not only the theft, but also his audacity to enter a church by force.

In any case, and as in the García de Escalante episode in Flanders, the victims failed to fulfil their demands through the channels of ordinary local courts, so they had to return to Castile to continue their legal proceedings. On this note, one should mention that it was very common to find other Spaniards in Ireland during the months of September to November, as the Basque and Castilian fishermen who had been fishing in those waters during the summertime would be setting out on their return journey home. ${ }^{27}$ Any of them could call at Bantry or surrounding towns and help out their compatriots in distress.

Pedro Gutiérrez de Comillas himself started legal proceedings once the entire crew had returned to their native kingdom. But before referring the case to justice in Valladolid, he wanted to mount an effective defence. To this end, he met with county authorities in San Vicente de la Barquera and formally recorded in writing the testimonies of his compatriots regarding the theft.

\footnotetext{
27 Beatriz Arízaga Bolumburu, ‘Gentes de mar en los puertos medievales del Cantábrico’ in Jesus A Solórzano Telechea, Michel Bochaca and Amelia Aguiar Andrade (eds) Gentes de mar en la ciudad atlántica medieval (Instituto de Estudios Riojanos, 2012) 19-62, 41.
} 
We do not know the ruling of the Castilian Royal Court of Justice, and therefore whether or not the efforts of Pedro Gutiérrez to recover his goods were successful. In any case, we can say that the confrontation between the San Vicente de la Barquera residents and the Beara locals was an isolated and specific event; in fact, the general trend in subsequent years, and until the late sixteenth century, would show an increase in the number of Basque and Castilian ships visiting the Irish coast in search of fish. ${ }^{28}$

The fifth case reported in this paper is the episode involving Fernando de Escalante and Juan de Agüero, two brothers (although with different surnames) from the town of Santander who in 1489 raided two Venetian ships loaded with cotton from Constantinople to a value of 30000 gold ducats. ${ }^{29}$ According to the Canon law of the time, a Christian was acting within the law if he stole from a Muslim ship, or if the ship was Christian but intended to supply Muslim cities. During the judicial proceedings, relatives of Fernando de Escalante and Juan Agüero claimed that the attack had been carried out lawfully, since it was performed 'legally within Moorish waters off the city of Constantinople' and because the attacked ships were providing supplies to Muslims. ${ }^{30}$ The prosecution replied that to legally attack a ship which was supplying Muslim cities, it was a prerequisite to have a specific letter of authority, which Fernando and Juan lacked.

\footnotetext{
${ }^{28}$ Wendy Childs and Timothy O'Neill, 'Overseas Trade', in Art Crosgrove (ed) A new History of Ireland (Clarendon Press, 1987) Vol II 492-524, 504.

${ }^{29}$ Jesús A Solórzano Telechea, Colección Documental de la Villa Medieval de Santander en el Archivo General de Simancas (1326-1498) (Concejalía de Cultura de Santander, 1999) 89; AGS RGS (1489) MS RGS,LEG,148903,53.

30 ibid, 97-98; AGS RGS (1490) MS RGS,LEG,149009,64.
} 
The appeal to ecclesiastical law was of no use. The assaulted boat belonged to Ulysses Salvador, an Italian merchant with many resources that he had no qualms in using in order to retrieve his belongings and punish his perpetrators. Ulysses Salvador had influence in Castilian high society; in fact, he appears as Venetian ambassador to Castile in 1491 . No wonder then, that two years earlier, shortly after the attack on the ships, Ulysses Salvador received a letter from the Catholic Monarchs ordering the capture of Fernando de Escalante and his brother. ${ }^{31}$ In other words, after a very short time Ulysses Salvador had managed to find out the identity of the thieves and make the Castilian Royal Court of Justice actively collaborate in his cause by sending a royal scribe called Pedro Sánchez de Arbolancha to Santander to act as investigator in the case.

When the investigator arrived at the town in February 1489, he found that Fernando de Escalante and Juan de Agüero were absent, and that there were no assets belonging to the suspects that could be seized as compensation. The investigator also discovered that, shortly before leaving the port, the two brothers had sold their assets to other family members, specifically to their mother and an uncle, so that if they were discovered the courts would not be able to commandeer any assets. There is documented evidence of similar cases from the time in which the suspects follow this pattern of behaviour, so this only confirmed the suspicions of the investigator. ${ }^{32}$

\footnotetext{
31 ibid, 88; AGS RGS (1489) MS RGS,LEG,148902,324.

32 Jose A García de Cortázar, Vizcaya en el siglo XV: aspectos económicos y sociales (Caja de Ahorros Vizcaina, 1966) 361.
} 
The next step taken by the investigator was to order the seizure of the personal and real property of the suspects' mother and uncle. ${ }^{33}$ However, this family belonged to the branch of the Barcenillas, a lineage with certain influence and standing within Santander. As a result, the efforts of the investigator to recover part of the assets of Ulysses Salvador by means of family assets were futile; on 14 March 1489, the brothers' mother managed to make the court return the assets seized by the investigator, as did the uncle of the accused four days later. ${ }^{34}$ The mother and uncle of the defendants argued that they had not received any benefit from the attack on the Venetians led by Fernando de Escalante and Juan de Agüero, and therefore could not be held responsible for the crime. But that did not convince Ulysses Salvador, who initiated legal proceedings against them.

Ulysses Salvador's trial against the Barcenillas was held a year and a half later, on 28 September 1490. A surprising range of evidence had been collected by the prosecution by that date; for example, they showed that Fernando de Escalante had visited Santander after the attack, which the defence admitted. Ulysses Salvador's report stated at the trial that Fernando was aware of his crime and was therefore fleeing from justice: it presented the image of a man who frequently had to change residence between inns and the homes of family and friends in order to avoid being caught. The prosecution even collected testimonies that located the two brothers in Valladolid a few months beforehand, hiding at an inn for many days. Ulysses Salvador and his men also discovered that the ship used in the attack had been sold before returning to Santander, and therefore had not sunk near the town, as the defence argued.

\footnotetext{
33 ibid, 89; AGS RGS (1489) MS RGS,LEG,148903,53.

34 ibid, 90; AGS RGS (1489) MS RGS,LEG,148903,237.
} 
This fact shows the extent to which Ulysses Salvador had a network of contacts in Castile in order to obtain useful and accurate information. His men closely followed the movements of the brothers, with the pressure on the suspects ultimately beginning to bear fruit. Juan de Agüero, the younger brother, surrendered to the court and went to the trial, but the whereabouts of Fernando de Escalante remained unknown. The court finally ruled in favour of Juan de Agüero, whom they found not guilty for the incident, because when the attack occurred he was a minor. By contrast, the same court sentenced the elder brother to death, who declared in default after failing to appear in court. ${ }^{35}$

Ulysses Salvador did not relent in his efforts to achieve justice; in August 1491, with the trial completed, the Venetian heard some rumours that Fernando de Escalante had returned to Santander, and immediately secured a letter from the Catholic Monarchs enabling the magistrate of Cuatro Villas to order the imprisonment and execution of Fernando. ${ }^{36}$ However, there is no evidence to show that he was found or executed. In fact, this is the last news that we have of Fernando de Escalante, so either he lived the rest of his life as an outlaw or, more likely, he acquired another identity.

\section{Conclusions}

The cases that have been presented in this study demonstrate the extent to which thefts resulting from attacks at sea were one of the biggest fears of merchants. Losing goods at sea due to an attack entailed additional monetary costs in all senses: initiating legal proceedings in distant lands; sending messengers and court representatives to reclaim the lost goods; and waiting for the outcome of local justice. The real frustration for the

\footnotetext{
35 ibid, 120; AGS RGS (1491) MS RGS,LEG,149110,226.

36 ibid, 118; AGS RGS (1491) MS RGS,LEG,149108,203.
} 
attacked merchant was that in the aforementioned cases the courts rarely ruled in favour of the claimant, rendering it necessary to start proceedings again in the victim's homeland.

We have also seen that a merchant with sufficient resources and influence, such as the Venetian Ulysses Salvador, could speed up legal proceedings and trials, but that even this could not guarantee the recovery of lost goods: Ulysses was unable to recover the stolen goods through the family assets of his attackers, and the most he achieved from the courts was a death sentence for his assailant, who in turn was missing.

Another important factor in all the cases presented is the information available. To make a claim before the courts, it was necessary for the merchant to identify his attackers, and this was a difficult task to undertake by himself. In contexts such as we have described, in other words when the merchant was visiting foreign countries, it was important to count on the help of other fellow seafarers. In this sense, professional groups such as guilds (both formal and informal) were very useful, because merchants could use them to access information that was difficult to find by themselves. Merchants trading in foreign lands were aware that the help of their rival compatriots would help both sides out in the long term. At the same time, working together united them as a group, which would give rise to higher profits when they were trading privileges, reaching agreements or making claims to local authorities.

Once the merchant identified the attackers, he would then be able to make a claim before the courts with certain guarantees. The fact that in the cases we have studied the local courts ruled in favour of their own subjects does not mean that this was always the 
case. In fact, we should recall how the Castilian crown did not obstruct the proceedings initiated by Ulysses Salvador, and judging from the dates it was a quick trial.

By contrast, this speed was not enjoyed by Fernando del Hoyo, whose letter of marque and reprisal, even though it was legally executed on a Flemish subject, entailed so many problems for the Crown and the affected parties for over twenty years. And we do not even know whether the decision of the monarch to change the letter of marque for the role of councilman was ultimately executed.

Finally, after an evaluation of all the cases presented, we can provide a more avouched response to some of the questions that were posed at the beginning of this paper. We cannot state that maritime attacks were common practice, but we should admit that they existed and were a reality in the daily lives of merchants sailing the seas in search of profits.

Some of the judicial and extrajudicial processes that we have presented in the cases described are proof of the herculean efforts that merchants would make to recover lost goods. This would involve significant expenses: paying people to acquire information; travelling abroad; dealing with authorities; paying court representatives, and so on. If attacks had been commonplace and the affected parties had to continuously bring legal action, late medieval trade in the late fifteenth and early sixteenth centuries would have collapsed.

What we found is quite the opposite: concern from the highest institutions to avoid a decline in trade with other kingdoms, which was manifested in their reluctance to grant 
letters of marque and reprisal, and in their willingness to address the problems of merchants. In this regard, we should recall how the English crown processed and granted letters in favour of Juan de Urueña and his consorts, or the agreements of Fernando del Hoyo with the Castilian crown to return the seized goods to Cornelis Deque. Paradoxically, local or municipal institutions were more lax when condemning robberies and attacks perpetrated within their jurisdiction. This possibly explains why in local contexts the protection of the community was given more priority than the stability of trade. 